\title{
The Impact of Model Based Learning (MBL) in Improving Students' Understanding in Heat and Heat Transfer Concept
}

\author{
Mutia Hariza Lubis ${ }^{1}$, Ika Mustika Sari ${ }^{2}$, Parlindungan Sinaga ${ }^{3}$

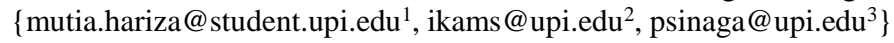 \\ Department of Physics Education, Faculty of Mathematics and Natural Sciences \\ Education,Universitas Pendidikan Indonesia Universitas Pendidikan Indonesia, Jl. Dr. Setiabudhi 229 \\ Bandung 40154, Indonesia ${ }^{1,2,3}$
}

\begin{abstract}
Heat and heat transfer concepts are difficult concepts due to the abstract characteristics. Therefore, efforts are needed to improve the students' understanding of concepts and minimize misconceptions. Model Based Learning (MBL) is a learning model which presents a scientific model as an illustration of an abstract concepts and facilitates students to reconstruct their model. This study used Pre-Experimental method with One Group Pretest-Posttest Design. The sample in this study consisted of 34 class X students of one of public high schools in Bungo Regency, Jambi Province, taken by convenience sampling. The instruments used were heat concept inventory contains 18 multiple choices questions. The results showed that there was an increase in students' understanding concepts in heat and heat transfer which was included in the medium category after the implementation of MBL. We can conclude that MBL is an effective model to improve students' understanding in heat and heat transfer concepts.
\end{abstract}

Keywords: Model Based Learning (MBL), Students' Understanding Concepts

\section{Introduction}

Physics is one of the subjects that are the basis of science and technology knowledge that is closely related to daily life [1] Physics elaborates on natural phenomena in physical form and requires comprehensive high-level understanding [2,3]. Phenomena in physics are studied empirically, logically, systematically, and rationally involving processes and attitudes. Phenomena studied include observable and unobservable. Observable is an object that can be observed directly using the sense of sight, such as pendulum motion and the shape of an object. While unobservable are objects that cannot be directly observed using the sense of sight, such as the composition of water molecules, the solar system, and the surface of an object both rough and smooth. Besides, physics also has abstract concepts. According to the Indonesian Dictionary (KBBI) [4], abstract means not tangible or formless, for example, atoms, electrons, electric current, energy, and others. The use of abstract words and unobservable errors often occur. Abstract and unobservable are two different terms. The abstract concept is unobservable. Whereas unobservable is not necessarily abstract.

Sari [5] says that students' understanding of heat is still dominated by the definition written in the textbook. In the other study, Sari, dkk [6],[7] shows that in predicting phenomena, students used common sense and unscientific rather than used scientific. Suhendi [8] shows that 
there are still misconceptions about the concept of heat transfer, namely: 1) heat transfer by conduction is accompanied by molecular displacement; 2) the heat flow rate needed to increase the temperature of a substance is only influenced by the final temperature of the object and does not consider the thermal conductivity of the object; 3) heat transfer by convection is accompanied by collision between molecules; 4) perfect black matter will absorb or emit bad heat; and 5) brightly colored surfaces absorb or emit good heat. In line with research conducted by Yolanda, et al [9], using the Thermal and Transport Concept Inventory (TTCI) instrument equipped with Certainty of Response Index (CRI) and interviews obtained by students experiencing misconceptions on all concepts tested, namely $32 \%$ in the concept of expansion of substances, $44 \%$ in the concept of change in length increases to temperature changes, $45 \%$ in the concept of anomalous nature of water, $83 \%$ in the concept of phase change, $53 \%$ in the concept of the rate of heat input to temperature changes, $52 \%$ in the concept of temperature shared equally and $82 \%$ on the concept of the relationship of heat capacity with temperature changes. Also, based on research conducted by Amalia, et al [10] it is known that there is a lack of knowledge of the concept of heat transfer, temperature changes, and thermal properties by $49 \%$ and a misconception in heat concept by $46 \%$.

The high misconceptions that occur indicate that the learning process has not been able to make students understand the concepts of heat and heat transfer well. Therefore, we need a learning model that can minimize the occurrence of misconceptions and be able to increase students' understanding concept of heat and heat transfer. Sari, dkk [11] say that Model based learning is now relevant and necessary with Physics learning. This is supported by Etikamurni [12] which states that learning models that emphasize the application of a conceptual model have proven to be quite effective in increasing students' understanding concepts in temperature and heat. Model Based Learning (MBL) is a learning model that uses scientific models that can describe abstract concepts to improve students' understanding of concepts. In addition to presenting a model, students are also expected to be able to reconstruct their models. Referring to the diagram proposed by Justi [13], the researcher tries to present a model and modeling done by students in learning using Model Based Learning (MBL) in Table 1 with the syntax adopted and adapted from the model of modeling diagram in the heat and heat transfer, so students learn the concepts well.

Table 1. Syntax Model Based Learning (MBL)

\begin{tabular}{|c|c|c|}
\hline $\begin{array}{c}\text { Model Based Learning } \\
\text { (MBL) }\end{array}$ & Knowledge & $\begin{array}{c}\text { Students' Understanding } \\
\text { Concept }\end{array}$ \\
\hline Demonstration & To observe & Remember \\
\hline Drawing & $\begin{array}{l}\text { To make predictions through } \\
\text { drawing }\end{array}$ & Understand \\
\hline Simulation & To design simulations & Analysis \\
\hline Evaluation & $\begin{array}{l}\text { To perform simulations from } \\
\text { drawing }\end{array}$ & Apply \\
\hline Reinforcement & To make conclusions & Analysis \\
\hline
\end{tabular}

\section{Research Method}

This study used the Quasi-Experimental Design with One Group Pre-Posttest Design to investigate students' understanding of heat and heat transfer concepts with Model Based 
Learning (MBL). Research participants consist of 34 students of class XI who have not yet and will study heat and heat transfer in one of the senior high schools in Bungo Regency, Jambi Province. Data collection techniques in this study used a students ${ }^{6}$ understanding concept test instrument in the form of multiple-choice consisting of 18 questions. The questions contain temperature, molecular structure, heat, the effect of heat on temperature and molecular arrangement, expansion, heat conductivity, heat capacity, heat transfer, and black principle. The test used to investigate students' understanding of concepts. Then, data treated with N-gain to see the improving students' understanding concepts that occur. In addition to the test instrument, the implementation of Model Based Learning (MBL) was seen using an observation sheet filled by several observers.

\section{Result and discussion}

\subsection{The Implementation of Model Based Learning (MBL) for Improving Students 6 Understanding Concept}

Model Based Learning (MBL) is a learning model that uses scientific models to improve students' understanding of concepts. The topics in this learning are heat and heat transfer which is considered to require models and modeling to be understood by students. Treatment in this research is Model Based Learning (MBL) which is given in two meetings. Before giving treatment, students are given a pretest first. Meanwhile, after giving treatment, students are given a posttest using the same questions as the pretest. At the first meeting, students discuss temperature, the characteristics of the molecules making up a substance, heat, and expansion. While at the second meeting, students discuss the black principle and heat transfer. In these two meetings, learning takes place following the syntax that was previously prepared. The implementation of learning through the observations of three observers at each meeting. Each observer observes and gives a checklist on the observation sheet that has been provided. Observation sheets have been coordinated with each observer beforehand to avoid misunderstandings when filling out the observation sheets by the observer. The following results of the implementation of learning are presented in Table 2 below:

Table 2. Implementation of Model Based Learning (MBL).

\begin{tabular}{lcccccc}
\hline \multirow{2}{*}{ Activities } & \multicolumn{3}{c}{$1^{\text {st }}$ meeting } & \multicolumn{3}{c}{$2^{\text {nd }}$ meeting } \\
\cline { 2 - 7 } & $\mathrm{O} 1$ & $\mathrm{O} 2$ & $\mathrm{O} 3$ & $\mathrm{O} 1$ & $\mathrm{O} 2$ & $\mathrm{O} 3$ \\
\hline Teacher & $100 \%$ & $100 \%$ & $100 \%$ & $75 \%$ & $75 \%$ & $75 \%$ \\
Student & $88 \%$ & $78 \%$ & $88 \%$ & $69 \%$ & $78 \%$ & $84 \%$ \\
$\sum_{\text {Average }}$ & \multicolumn{5}{c}{$\begin{array}{c}85 \% \\
\text { Criteria }\end{array}$} & \multicolumn{5}{c}{$78 \%$} & \\
\hline
\end{tabular}

Based on Table 2, an average of implementation of Model Based Learning (MBL) is $85 \%$ which included in the criteria of almost all activities carried out, both teacher activities by $92 \%$ and students by $78 \%$ even though they were still not fully implemented. The implementation of Model Based Learning (MBL) is still not optimal. This is because this research was conducted outside of class hours or upright hours. This research was conducted at the time the students had carried out the final semester exams and were carrying out activities class meetings. This makes 
students less focused on learning, especially at the second meeting, where activities class meeting are already going well.

\subsection{The Improving Students ${ }^{6}$ Understanding Concept}

Based on Table 3, the average score of the pretest and posttest of the experimental class was 3.88 and 12.85. The acquisition of $\mathrm{N}$-gain after applying the Model Based Learning (MBL) of 0.64 is included in the medium category.

The topic taught in the experimental class and the control class is heat and heat transfer. So the test instrument used to measure the students ${ }^{6}$ understanding concepts related to the topic amounted to 18 questions which were then divided into 6 aspects. The following is a graph of the students' understanding concept of each aspect.

Table 3. N-gain Test Result of Students` Understanding Concept.

\begin{tabular}{lcc}
\hline & Pretest & Posttest \\
\hline Score max & 18 & 18 \\
Average score & 3,88 & 12,85 \\
N-gain & \multicolumn{2}{c}{0,64} \\
Category & \multicolumn{2}{c}{ Medium } \\
\hline
\end{tabular}

From Figure 1, information is obtained that improving students' understanding concepts in aspects 1 (temperature and molecular arrangement) is included in the high category, whereas for aspect 2 (heat and the effect of heat on temperature and molecular arrangement), 3 (expansion ), 4 (heat conductivity and heat capacity), 5 (heat transfer), and 6 (thermal equilibrium) are included in the medium category. Besides being high in counts, students also understand the concepts learned in heat and heat transfer especially in the aspect of temperature and molecular arrangement. This can occur because of new activities in learning, namely drawing and simulation. The activity can create enthusiasm for students who are driven by curiosity. Besides, demonstration and reinforcement also contribute to attracting attention and strengthening the concept of students.

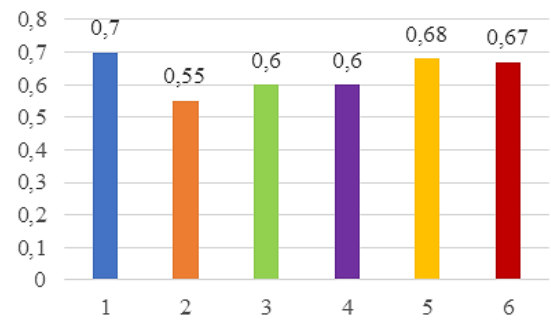

Fig. 1. N-gain for each aspect.

Information:

1. Temperature and molecular arrangement

2. Heat and the effect of heat on temperature and molecular arrangement

3. Expansion

4. Heat conductivity and heat capacity 


\section{Heat transfer}

Thermal equilibrium

\section{Conclusion}

Based on the data and the results of the discussion it was concluded that there was an improving in students' understanding in the heat and heat transfer concept after the application of Model Based Learning (MBL) was seen from the N-gain that 0.64 included in the medium category.

\section{References}

[1] Saregar, A.: Pembelajaran Pengantar Fisika Kuantum Dengan Memanfaatkan Media Phet Simulation Dan LKM Melalui Pendekatan Saintifik : Dampak Pada Minat Dan Penguasaan Konsep Mahasiswa. Jurnal Ilmiah Pendidikan Fisika Al-Biruni. Vol. 5(1), pp. 53-60 (2016)

[2] Sasmita, P. R.: Penerapan metode inkuiri terbimbing menggunakan media kit fisika: upaya meningkatkan aktivitas dan hasil belajar fisika siswa. Jurnal Ilmiah Pendidikan Fisika AlBiruni. Vol. 6(1) pp. 95-102 (2017)

[3]Susiharti, \& Ismet.: Studi Kesalahan Siswa dalam Menyelesaikan Soal-Soal Vektor di SMA Negeri 1 Inderalaya. Jurnal Inovasi Dan Pembelajaran Fisika. Vol. 4(1), pp. 99-105 (2017)

[4]Badan Pengembangan dan Pembinaan Bahasa, Kementerian Pendidikan dan Kebudayaan Republik Indonesia. Kamus Besar Bahasa Indonesia. Retrieved from https://kbbi.kemdikbud.go.id/ (2016)

[5]Sari, I. M.: What do they know about Heat and Heat Conduction? A case study to excavate Preservice Physics Teachers' Mental Model in Heat and Heat Conduction. In Journal of Physics: Conference Series. Vol. 812, No. 1, pp 012090). (2017)

[6]Sari, I. M., and Saepuzzaman, D.: Physics Students' Mental Model and Prediction in Heat Convection Concept. In 2015 International Conference on Innovation in Engineering and Vocational Education. Atlantis Press. (2015)

[7]Sari, I. M., Fauzi, D., Malik, A., Saepuzaman, D., Ramalis, T. R., and Rusdiana, D.: Excavating the Quality of Vocational Students' Mental Models and Prediction on Heat Conduction. In Journal of Physics: Conference Series, Vol. 1204, No. 1, pp. 012042 (2019)

[8]Suhendi, H.Y.: Penerapan Model Pembelajaran ECIRR Berbantuan Media Simulasi Virtual Untuk Meningkatkan Pemahaman Konsep Dan Mengidentifikasi Miskonsepsi Siswa. S2 thesis, Universitas Pendidikan Indonesia. (2014)

[9]Yolanda, R., Syuhendri, S. and Andriani, N.: Analisis pemahaman konsep peserta didik SMA Negeri se-kecamatan Ilir Barat I Palembang pada materi suhu dan kalor dengan instrumen TTCI dan CRI (2015)

[10]Amalia, R., Sari, I.M. and Sinaga, P.: Students' mental model on heat convection concept and its relation with students' conception on heat and temperature. In Journal of Physics: Conference Series, Vol. 812, No. 1, pp. 012092 (2017)

[11]Sari, I. M., Malik, A., Saepuzaman, D., Rusdiana, D. and Ramalis, T. R.: Pre-service physics teachers' mental models of heat conduction: a case study of the process-analogy of heat conduction. In Journal of Physics: Conference Series, Vol. 1157. No. 3 pp. 032073) (2019)

[12]Etikamurni, D. P. and Sutopo, S.: Peningkatan Penguasaan Konsep Siswa Kelas XI IPA pada Materi Suhu dan Kalor melalui Modeling Instruction. Jurnal Pendidikan: Teori, Penelitian, dan Pengembangan, Vol. 4(2), pp. 172-177 (2019)

[13]Justi, R.: Learning how to model in science classroom: Key teacher's role in supporting the development of students' modelling skills. Educación química, Vol. 20(1), pp. 32-40 (2009) 